\title{
CRITICAL ASSESSMENT OF NIGERIA CRIMINAL JUSTICE SYSTEM AND THE PERENNIAL PROBLEM OF AWAITING TRIAL IN PORT HARCOURT MAXIMUM PRISON, RIVERS STATE
}

J. K. UKWAYI AND J. T. OKPA

(Received 4, May 2017; Revision Accepted 5, June 2017)

\begin{abstract}
The essence of incarceration is for correctional purposes, however, the ineffectiveness of the Nigeria Criminal Justice System (NCJS) have denied most suspects the privilege of enjoying these correctional privileges. This study therefore assessed the Nigeria criminal justice system and the problem of awaiting trial in Port Harcourt Maximum Prison, Rivers State. Three research questions were raised to guide the study. The study adopted the survey research design. An 18-item questionnaire captioned "Questionnaire on Nigeria criminal justice system and awaiting trial problem" (QNCJSWTP) was designed by the researchers and used in gathering data for the study. Data were gathered from one hundred and eighty seven (187) respondents consisting of inmates and warders. The respondents were purposively selected from Port Harcourt Maximum prison, Rivers State. The generated data were presented using charts and simple percentage. Findings indicated that, rigidity of the penal law, holding charges, and delay in the disposal of cases by the agencies of NCJS has contributed to the problem of awaiting trial in Port Harcourt Maximum Prison, Rivers State, Nigeria. The study recommended that, there should be more professional commitment, on the part of stakeholders, in order to check the rise in awaiting trial problem in Port Harcourt maximum Prison.
\end{abstract}

KEYWORDS: Nigeria criminal justice system, awaiting trial, rigidity of the penal law, holding charges, delay in the disposal of cases.

\section{INTRODUCTION}

The Nigeria criminal justice system (CJS) over the years has played a crucial role in the maintenance of law and order. The system according to Moses (2011) is an embodiment of crime regulating techniques, which represents the whole range of government agencies that functions as the instrument of the state to enforce its set rules necessary for the maintenance of peace, order, and tranquillity. The task of Criminal Justice System is carried out through the means of detecting, apprehending, prosecuting, adjudicating, and sanctioning those members of the society who violate its established laws Ugwuoke (2010). The effectiveness of the system is measured by its ability to meet the goals of deterrence, incapacitation, retribution, rehabilitation, and reintegration. The realization of such goals depends on the level of coordination among the various components of CJS. Regrettably, the outrageous number of inmates awaiting trial in prisons across the country has called to question the effectiveness of the Nigeria criminal justice system. Oti (2016) reported that eighty (80) percent of Nigeria prisons population are awaiting trial, most of whom, are held for trivial offences that are bailable.

The awaiting trial (AT) problem in Nigeria

J. K. Ukwayi, Department of Sociology, University of Calabar, Calabar, Cross River State, Nigeria.

J. T. Okpa, Department of Sociology, University of Calabar, Calabar, Cross River State, Nigeria. 
prisons without doubt, has created worry among stakeholders. This concern is further compounded with the continual rise in prison population across the country, which currently stands at seventy two thousand $(72,000)$ inmates (IPCR, 2017). The Port Harcourt Maximum Prison, designed from inception to accommodate eight hundred and four (804) inmates; presently houses about three thousand eight hundred and twenty four (3824) inmates, with over three thousand, four hundred and twenty two (3422) inmates in AT list (Azubuike, 2016). The continuous increase in the population of suspects awaiting trial in Port Harcourt Maximum Prison is traceable to institutional failure as well as ineptitude of law enforcement agencies and other state apparatus, charge with the responsibilities of propelling prosecution of criminal cases in the state (Uwais, 2004). This perennial challenge has led to a number of problems such as 2011,2015 jailbreak, and attempted jailbreak of 2016. This development has its attendant security risk as both convicted and detained prisoners escaped during jailbreak without trace. The ATP challenge has further resulted in many health related problems like scabies, asthma, tuberculosis, rashes, and HIVIAIDS (Jarma, 1999). Others include inadequate feeding, poor clothing, over used amenities, shortage, or dilapidated welfare rehabilitation facilities. The problem of awaiting trial has also posed serious management problems as can be seen in the inability of prison management to separate hardened criminals from minor offenders (Otite \& Albert, 2004). Amnesty International (2008) reported that the problem of awaiting trial persons and their unsatisfactory living conditions increases the chances of aggression among suspects and can result to unrest and other cruel behaviour in the prison.

In an attempt to address the afore mention problems in Nigeria prisons, successive governments (military and civilian) have set up panel of inquiries, committees, and initiated reform programmes designed to improve the general well-being of inmates and to restructure the criminal justice system for efficient service delivery. Regrettably, most of these attempted reforms have failed to yield the expected results, leading to plethora of studies and debates on this subject matter. In addition, most of the studies have not availed researchers and policy-makers necessary empirical information, thus the need for this study. This study is, therefore, designed to critically assess the Nigeria criminal justice system and the problem of awaiting trial in Port Harcourt Maximum Prison, Rivers State. The following research questions were raised to guide the study: How does the rigidity of the penal law contribute to awaiting trial problem in Port Harcourt Maximum Prison? What is the relationship between holding charges and awaiting trial problem in Port Harcourt Maximum Prison? To what extent has the delay in the disposal of cases contributed to the awaiting trial problem in Port Harcourt Maximum prison?

\section{Aims of the study}

The study sought to critically assess the Nigeria criminal justice system and awaiting trial problem in Port Harcourt Maximum Prison, Rivers State. The specific objectives are to:

(i) Examine the relationship between the rigidity of the penal law and awaiting trial problem in Port Harcourt Maximum Prison

(ii) Determine the relationship between holding charges and awaiting trial problem in Port Harcourt Maximum Prison

(iii) Establish the relationship between delay in the disposal of cases and awaiting trial problem in Port Harcourt Maximum Prison

\section{Scope of the Study}

The scope of this study is limited to the Nigeria criminal justice system and awaiting trial problem in Port Harcourt Maximum prison. Specifically, the study is limited to measurable variables like rigidity of the penal law, holding charges, and delay in the disposal of cases. The dependent variable is (Awaiting trial problem ATP). The institutional scope of this study is Port Harcourt Maximum Prison, while the geographical scope is Rivers State, Nigeria.

\section{REVIEW OF RELATED LITERATURE}

\section{Rigidity of the penal law and the ATP problem}

The rigidity of the Nigeria penal code is absurd and disheartening; it has remarkably contributed to the problem of ATP across prisons in Nigeria. A penal law is imperative in the realization of justice in any human society. It is an instrument used by the state against individuals' actions that contradict established norms and laws (Ndifon, 2012). Abuchi (2013) reported that the justice system in Nigeria is not flexible, 
tolerant, and liberal like that of developed nations of the world. The standard practice globally according to Abuchi (2013), is that persons indicted for trivial offences like violating traffic rules, fighting, among other minor crimes are asked to pay fine, participate in community service or pay back what they have wrongfully collected from others. Abuchi (2013) observed that in Nigeria, reverse is the case, as the prisons in Nigeria are filled with inmates who have been convicted of minor offences. This has significantly contributed to the problem of prison congestion in Nigeria.

\section{Holding charges and the ATP problem}

According to Black's Law Dictionary, the phrase 'holding charge' is defined as a criminal charge of some insignificant crime filed to keep the accused in detention while the persecutor takes time to build a bigger case and prepare a more serious offence. Similarly, Tolupe Adekola defined the term as a system of bringing an accused person before an inferior court that lacks jurisdiction to try him or her for the primary purpose of securing a remand order and thereafter abandon him or her in prison under the pretence of awaiting trial. In the same vein, the former Chief Justice of Nigeria (CJN), Dahiru Musdapher stated that the term holding charge is a system whereby citizens are dumped in prison by a court, which lacks jurisdiction to try them. The essence of holding suspects in detention is to allow law enforcement officers carry out proper investigations with a level of certainty as to his availability when required. Thus, the basis for the use of holding charge is to ensure that an accused person does not jump bail when the court requires him to answer to the allegations against him.

Stakeholders have argued that holding charges are responsible for rising number of ATP in Nigeria's prison, and as such, a major source of prisons congestion (Chigozie \& Ajah, 2011, Ukwayi, Okpa, Adewoyin, Angioha, Udom, 2017). These scholars observed that the overwhelming number of awaiting trial persons in Nigeria prisons is frightening and need not be overemphasised. There are empirical proofs that support the contention by stakeholders that many of the accused persons behind the prison bars, after appearing in court on holding charges end up spending periods ranging from one week to seven years in detention (Agbakoba \& Ibe, 2004). Jiti Ogunye reported that holding charge is the principal reasons why criminal trial in Nigeria is largely regarded as unfair. It is one of the rationale behind the large number of awaiting trial persons in Nigeria's prison, and as such a strong determining factor of prisons congestion.

The Nigeria law stipulates that, when an accused person is arrested he or she should be arraigned before a court of competent jurisdiction within 24 hours. The law did not make provision for "holding charges". Justices of the Appellate Court and Supreme Court of Nigeria have reported that the practice of "holding charges" is unconstitutional and illegal.The fact that it is being practiced by the Police brings to the fore one of the problems of our criminal justice system. The problem arises from the inadequacy of the Police. The Police cannot cope with the 24 hours constitutional requirement within which they were supposed to arraign a suspect in court. They therefore rush to the court and secure an order of remand against an accused person pending when they would conclude their investigation. Holding charge is therefore being applied to cover up the inadequacies of the police and those vested with the duty of investigating cases. It is a way of covering their inefficiencies and inadequacies. The negative consequences of this operational ineptitude of the Nigeria police force are seen in the ever-increasing number of awaiting trial persons, which is partly responsible for prison congestion.

\section{Delay in the delivery of justice and the problem of ATP}

Ibanga (1996), Igbo (1999) and Imiera (2005) reported that access to justice is an essential part of any criminal justice system. Access to justice entails, having adequate legal support and undue interruption in the dispensation of justice. Delay in the delivery of justice, is largely responsible for the problem of ATP, which results to prisons congestion. Ibanga (1996) posits that delay in court proceeding and ATP problem throughout the country threaten the safety and security of lives and properties. He contends that as delay in criminal prosecution increases, the innocent who cannot afford to make bail suffer longer in jail. Some schools of thought believe that the delay in discharge of justice is the remote cause of ATP problem in Nigeria prisons (Alemika \& Chukwuma, 2006).

ATP in Nigeria prisons cannot be discussed without mentioning the judiciary because the problem is partly the outcome of delay judgement. Contrary to good judicial practice, most of these ATPs have been on trial 
for periods longer than necessary which constitute abuse of human rights. This could be very frustrating and capable of eliciting violent behaviour from the affected inmates. The correctional institution, though an integral part of the system lacks the capacity to move the ATPs outside the arena of the judiciary where they are going through trial. Regrettably, the third tier of the criminal justice system (Prison) bears the brunt, of the ineptitude of the system it belongs. This phenomenon has resulted to the inability of the prison management to manage the prison population effectively.

Delays encountered in the processing of cases before a final sentence is passed, have a significant impact on the size of the pre-trial prison population in many countries including Nigeria (Ayo, 2008). While in some countries detainees will spend only short periods in pre-trial detention, in many others, pre-trial detention periods can extend to months and years. In capital cases in particular, prisoners may spend up to ten years or more awaiting trial. These long delays can be due to a combination of many factors, usually mutually reinforcing, which include; interruptions during criminal investigation, disconnection in communication between police, prosecutor and the court, bureaucracy in court proceeding, incessant adjournment of cases occasioned by shortage of judges, absence of witnesses, lack of transport to take accused person to court, lack of security for transport (particularly in crisis area) and lack of proper filing and tracking systems in prisons to ensure that pre-trial detainees are taken to court on dates fixed by the court system.

\section{THEORETICAL EXPLANATION}

\section{Structural functionalism theory}

The theory views society as a single interconnected social system, each element of which performs a definite function (Ottong, 2004). The basic characteristic is the integration of its components and functional integration of system occasioned by interdependence of parts. The theory recognizes equilibrium in the social system (Ottong, 2004). Structural functionalism theory appears to be the right framework to adopt for this survey. This is because the framework views human society as a system made up of interdependent and interrelated components which function in unity to make a whole and that the component parts function harmoniously for the benefit of the whole social system. The harmonious functioning of the entire system helps in the actualisation of the needs of the system; this enables the system not to break down. In this study, the component parts of the social system are the law enforcement agencies, the judiciary and the correctional institutions that must work harmoniously to maintain the efficient functioning of the Nigeria criminal justice system in order to manage the awaiting trial problem in Nigeria prison.

This sociological perspective recognizes equilibrium in the social system.However, where the component parts fail to function efficiently, social disequilibrium sets in. Within the context of this study, the awaiting trial problem caused by rigidity of the penal code, holding charges, delay in the delivery of justice is responsible for the disequilibrium occurring in the system. Therefore, the inability of the correctional institutions, the judiciary, and the law enforcement agency to discharge their constitutional mandate creditably well is partly responsible to awaiting trial problem in Rivers State Prisons, Nigeria.

\section{METHOD}

The study adopted survey research design. The researcher opted for this design because it is used to study people's feelings and perception about social phenomenon such as AT problem in Rivers Prison. The design promotes the utilization of questionnaire in gathering data; this makes it cheaper as compared to other designs (Isangedighi, Joshua, Asim \& Ekuri, 2014). More so, the design allows for the selection of samples and drawing of inferences from the sample. The study was carried out in Port Harcourt, Rivers State, Nigeria. Port Harcourt is the capital of Rivers state and the economic hub of the state. The city lies along the Bony Rivers and is located in the Niger Delta Region. The Port Harcourt maximum-security prison is situated in the state capital. According to Azubuike (2016), the population of inmates in Port Harcourt Prison is three thousand, eight hundred and twenty four (3824), with three thousand, four hundred and twenty two (3422) inmates in ATP list.The study purposively selected 149 inmates and 38 warders from the prison yard. The total number of 187 respondents was selected for this study. The instrument for data collection was 18 items questionnaire entitled "Nigeria Criminal Justice System and the Problem of Awaiting Trial" (NCJSPATQ). Elucidated data were coded and analysed using simple percentage and charts. 
Presentation of research findings

The research instrument was

administered to one hundred and eighty seven (187) respondents with the help of two prison warders. The respondents for this study consisted of inmates (male and female) serving jail terms, awaiting trial persons and prison warders. Each respondent was given a copy of the questionnaire. Explanations were given to respondents who donot understand certain questions or items in the instrument.Out of the 187 copies of the questionnaire distributed, only 181 were returned and used for the analysis.

The spread of respondents with respect to 'demographic data as discussed revealed with respect to gender, majority 87.8 per cent $(\mathrm{N}=$ 159) were male while only 12.2 per cent $(N=22)$ were female. The responses with regards to age shows that majority 37.0 per cent $(\mathrm{N}=67)$ were between 26-35 years, followed by respondents below the ages of 25 years were 28.2 per cent $(\mathrm{N}$ $=51$ ), responses from ages of 36-45 years were 16.0 per cent $(N=29)$, responses from ages of 46-55 years were 11.6 per cent $(N=21)$, while those from 56 years and above had a representation of 7.2 per cent $(N=13)$. The distribution of respondents by marital status showed that majority of the respondents 70.2 per cent $(N=127)$ were single; 27.1 per cent $(N=49)$ were married, while 2.8 per cent of the respondents $(N=5)$ were divorced. The distribution of respondents by prison status showed that majority of 95.0 per cent $(\mathrm{N}=172)$ respondents were in the ATP list, 5.0 per cent $(\mathrm{N}=9)$ are convicts while none of the respondents is on death roll. The spread of respondents in terms of their stay in prison shows that majority 48.6 per cent $(\mathrm{N}=88)$ have stayed below 5 years, 37.0 per cent $(\mathrm{N}=67)$ have stayed between 6-10 years, 8.3 per cent $(N=15)$ have stayed between
11-15 years, 6.1 per cent $(N=11)$ have stayed between $16-20$ years.

\section{ANSWERING RESEARCH QUESTIONS}

\section{Question one}

Question one, states that how does the rigidity of the penal law contribute to awaiting trial problem in Port Harcourt Maximum Prison, Rivers State? Fig 1 shows the responses of respondents to question one. As revealed in fig 1, all the respondents answered "Yes" to all the items in question one. Responses to question one which states that,the rigid nature of Nigeria laws has contributed to the awaiting trial problem in Port Harcourt maximum prison revealed that 95.0 per cent ( $\mathrm{N}=172)$ answered "Yes" while 5.0 (9) answered "No". Responses to question two which states that, most inmates in Port Harcourt maximum prison were arrested for minor offences and they constitute the bulk of awaiting trial persons revealed that 98.9 per cent $(\mathrm{N}=179)$ answered "Yes" while 1.1 per cent (2) answered "No". Responses to question three which states that, Inmates who have committed minor offences are locked up in prison where those who committed major offence are kept revealed that 100 per cent $(\mathrm{N}=181)$ answered "Yes" while 0 per cent (0) answered "No". Responses to this questions revealed that rigidity of the penal law has contributed to awaiting trial problem in Port Harcourt Maximum Prison, Rivers state, Nigeria. It therefore means that, awaiting trial problem is evident where offenders are detained for minor offences of which the law would have proffer lesser punishment or ask the offender to pay fine. This is evident from the responses of inmates and warders attached to Port Harcourt Maximum Prison, Rivers State. 


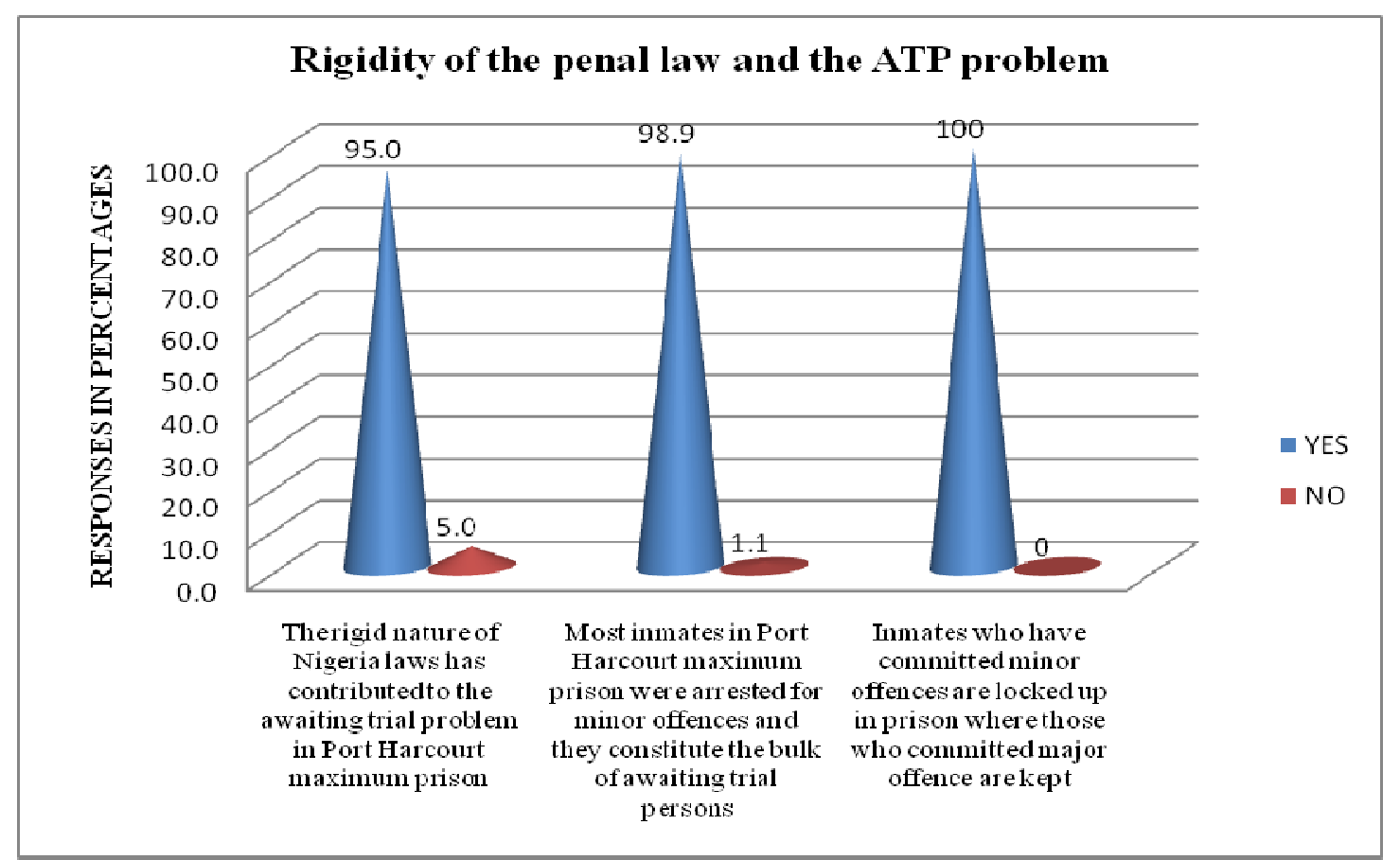

Fig 1: Pyramid bar chart showing the response of respondents on rigidity of the penal law and ATP problem

\section{Question two}

Question two, states that, what is the relationship between holding charges and awaiting trial problem in Port Harcourt Maximum Prison, Rivers State? Fig 2 shows the responses of respondents to question two. As revealed in fig 2, all the respondents answered "Yes" to all the items in question two. Responses to question ten which states that, police bring suspects to court when investigation is on-going to secure an injunction from court to remand suspects in prison custody revealed that 98.3 per cent $(\mathrm{N}=178)$ answered "Yes" while 1.7 (3) answered "No". Responses to question eleven which states that, the inability of Police to complete investigation at good time contributes to the awaiting trial problem in Port Harcourt prison revealed that 93.4 per cent $(\mathrm{N}=169)$ answered
"Yes" while 6.6 per cent (12) answered "No". Responses to question twelve which states that, charging suspects to court without full investigation is partly responsible for the awaiting trail problem in Port Harcourt prison revealed that 98.9 per cent $(\mathrm{N}=179)$ answered "Yes" while 1.1 per cent (2) answered "No". Responses to these questions revealed that holding charges has contributed to awaiting trial problem in Port Harcourt Maximum Prison, Rivers State, Nigeria. It therefore means that, the failure of the Nigeria Police Force to complete investigate before charging suspects to court has remarkably contributed to the awaiting trial problem in Port Harcourt Maximum Prison, Rivers State, Nigeria. This is evident from the responses of inmates and warders attached to Port Harcourt Maximum prison, state. 


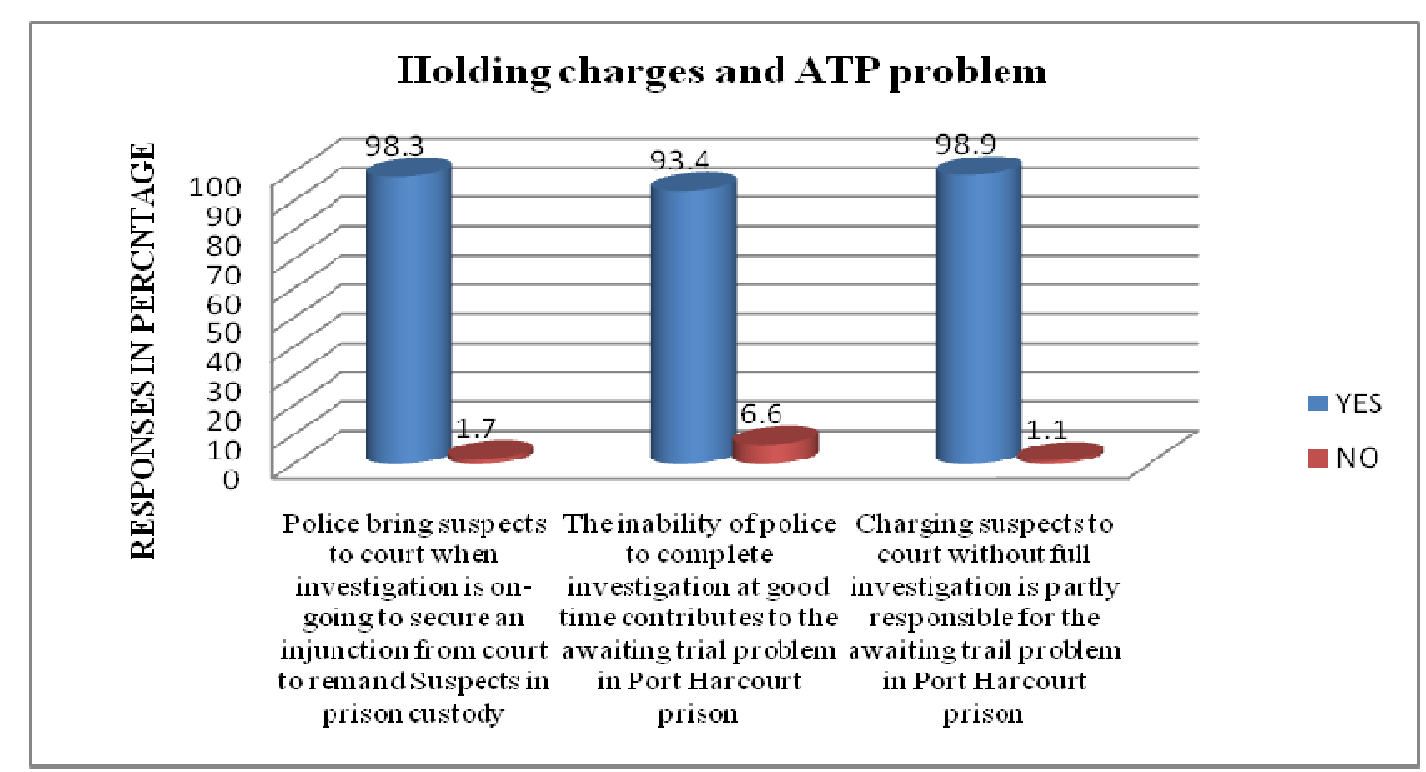

Fig 2: Cone bar chart showing the response of respondents on holding charges and ATP problem

\section{Question three}

Question three, states that to what extent has the delay in the disposal of cases contributed to the awaiting trial problem in Port Harcourt Maximum Prison? Fig 3 shows the responses of respondents to question three. As revealed in fig 3 all the respondents answered "Yes" to all the items in question three. Responses to question thirteen which states that, the large proportion of unresolved cases by the judiciary is responsible for awaiting trial problem in prison congestion in Port Harcourt prison revealed that 95.0 per cent $(\mathrm{N}=172)$ answered "Yes" while 5.0 (9) answered "No". Responses to question fourteen which states that, observing the principle of speedy trial by the court keeps defendants from sitting for an indefinite period in prison before trial revealed that 87.3 per cent $(\mathrm{N}=158)$ answered "Yes" while 12.7 per cent (23) answered "No". Responses to question fifteen which states that, timely resolution of criminal and civil cases increases the chances of inmate getting fair trial and reducing the awaiting trial problem in Port Harcourt prison revealed that 75.7 per cent $(\mathrm{N}=137)$ answered "Yes" while 24.3 per cent (44) answered "No". Responses to this questions revealed that delay in the disposal of cases has contributed to awaiting trial problem in Port Harcourt Maximum Prison, Rivers State, Nigeria. It therefore means that, the inability of the judiciary to try and dismiss both criminal and civil cases as at when due has remarkably contributed to the awaiting trial problem in Port Harcourt Maximum Prison, Rivers State, Nigeria. This is evident from the responses of inmates and warders attached to Port Harcourt Maximum Prison, Rivers State. 


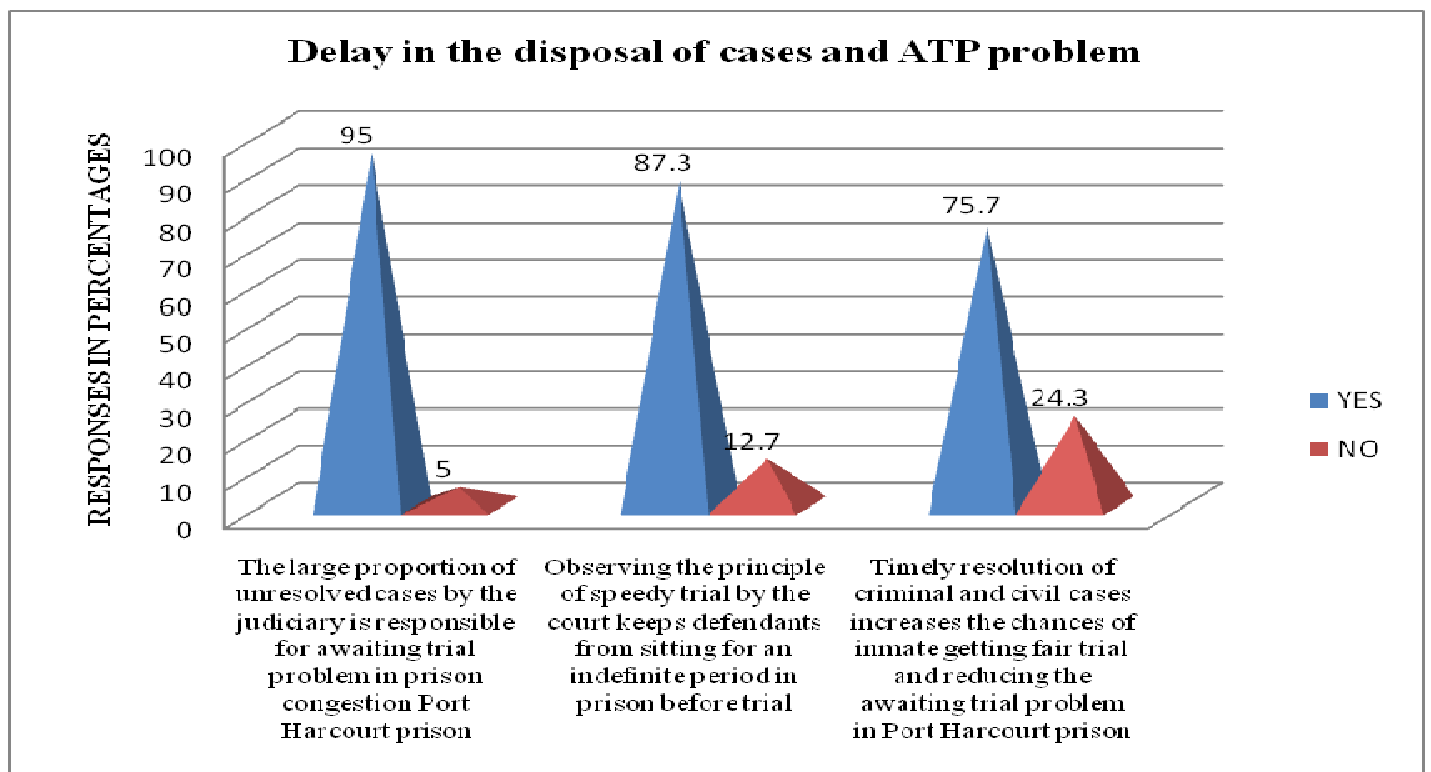

Fig 3: Clustered pyramid bar chart showing the response of respondents on delay in the disposal of cases and ATP problem

\section{CONCLUSION AND RECOMMENDATIONS}

The awaiting trial challenge in Port Harcourt Maximum Prison has led to the problem of congestion; this development has made the categorisation of inmates a herculean task for prison authorities. The implication is that hardened criminals are lump together with first timers thereby making reformation which is the main essence of incarceration a difficult task. The concern of this survey is to critically assess the Nigeria Criminal Justice System and the awaiting trial problem in Port Harcourt Maximum Prisons, Rivers State. The study observes that the failure of the CJS has made Port Harcourt maximum prison the second most populated prisons in Nigeria with about eighty percent of the inmates on AT list. Based on this revelation, the following recommendations are put forward:

(i) Government and other stakeholders should facilitate the completion of Omoku prison project in order to provide a more befitting accommodation for inmates and reduce the pressure on Port Harcourt prison

(ii) Suspects who have committed minor offenses and have stayed in prison for more than two years without trial should be granted unconditional pardon to decongest the prison. (iii) The three existing prisons in the state Port Harcourt, Degema and Elele Prisons should be renovated to help the inmates enjoy good living conditions while in incarceration.

(iv) The judiciary should develop the habit of discharging cases as at when do. This can be achieve by providing a conducive working environment for judges as well as reducing their work load.

\section{REFERENCE}

Abuchi, U. K., 2013. Prison congestion in Nigeria: Causes and solutions. Published by Assistant Superintendent of Prisons Maximum Security Prisons, Jos, Plateau State, Nigeria

Agbakoba, $\mathrm{O}$ and Ibe, S., 2004. Travesty of justice: An Advocacy Manual Against Holding Charge. Lagos: The Human Rights Law Service.

Alemika, E. E. O and Alemika E. I., 2002. Penal Policy, Prisons Conditions and Prisoners in Nigeria. Retrieved from: http://dspace.unijos.edu.ng/handle/10485 /1912/ 
Alemika, E. E. O and Chukwuma, I. C., 2006. Criminal Victimization, Security and Policing in Nigeria. Monograph series, No 6. CLEEN Foundation Lagos

Ayade, E. A., 2010. Problems of Prisons Overcrowding in Nigeria: Some lessons from South Africa and America. LLM, Human Rights, Unpublished Thesis, Central European University, Legal Studies Department, Budapest, Hungary.

Ayo, A. O., 2008. The Reformer. A Bulletin of Nigerian Prison Service/Changing the Face of Deviance, 4, (4):

Azubuike, V., 2016. Congestion: Port Harcourt Prison Now Houses 3824 Inmates. Daily Post News Paper.

Chigozie, I. C and Ajah A. O., 2011. Holding Charge and Pre-trial Detention vis-a-vis the Doctrine of Fair-Hearing in Nigeria. Lagos: The Lawyers Chronicle.

Ibanga, M. E., 1996. Learning Legal Theory and Legal Method. Calabar: Associated Publishers Ltd.

Igbo, E. U. M., 2007. Introduction to Criminology. Nsukka: Afro-Orbis Publication Ltd.

Imera, P., 2005. Legal Methods. Ibadan National Open University of Nigeria.

Isangedighi, A. J., Joshua, M. T., Asim, A. E and Ekuri, E. E., 2014. Fundamentals of Research and Statistics in Education and Social Science. Calabar: University of Calabar press.

Jarma, I. M., 1999. Prison and Reformation of Offenders. In A. B. Dambazau, M. M. Jumare \& A. M. Yakubu (Eds.), Issues in Crime Prevention and Control in Nigeria. Kaduna: Baraka Press.

Moses, U. I., 2011. The Nigerian Prison System and the Failure of Rehabilitation: An Examination of Incarceration a Aternatives. The Nigerian Academic Forum, 20, (1): 1-8.
Ndifon, C. O., 2012. Criminality and Sanctions: The Rhetoric and Reality of Nigerian Penal Policy. In American Journal of Scientific Research, Issue 63(2012) Euro Journals Publishing Inc. Retrieved from: http//www.eurojournals.com/ajsr/htm.

Oti, I. C., 2016. 80 Percent of the Inmates in Nigeria Prisons have not even been tried in court.

Otite, O and Albert, I. O., 2004. Community Conflicts in Nigeria: Management, Resolution and Transformation. Ibadan: Spectrum Books.

Ottong, J. G., 2014. The Study of Sociology: A Conceptual Approach. Calabar, Adonai Publishing House.

Ugwuoke, C. U., 2010. Criminology: Explaining Crime in the Nigerian Context. Nsukka: Great AP Express Publishers Ltd.

Ukwayi, J. K., Adewoyin, S. A., John, T. O and Ofem, N. O., 2017. Public Perception of Small Arms Epidemic and Conflict in Oke-Ogun Area of Oyo State, Nigeria.The International Journal of Humanities \& Social Studies, 5, (2): 100-108.

Ukwayi, J. K., Okpa, J. T., Adewoyin, S. A., Angioha, P. U and Udom, H. T., 2017. Security Equipment and Policing in Central Senatorial District of Cross River State, Nigeria IOSR Journal of Humanities and Social Sciences, 22, (2): 6-13. 
